\title{
Salidroside, 8(E)-Nuezhenide, and Ligustroside from Ligustrum japonicum Fructus Inhibit Expressions of MMP-2 and -9 in HT 1080 Fibrosarcoma
}

\author{
Hojun Kim ${ }^{1}$, Chang-Suk Kong ${ }^{2}\left(\mathbb{D}\right.$ and Youngwan Seo ${ }^{1, *}$ \\ 1 Division of Convergence on Marine Science, Korea Maritime and Ocean University, Busan 49112, Korea; \\ badguy47@naver.com \\ 2 Department of Food and Nutrition, Silla University, Busan 46958, Korea; cskong@silla.ac.kr \\ * Correspondence: ywseo@kmou.ac.kr; Tel.: +82-51-410-4328
}

check for updates

Citation: Kim, H.; Kong, C.-S.; Seo, Y. Salidroside, $8(E)$-Nuezhenide, and Ligustroside from Ligustrum japonicum Fructus Inhibit Expressions of MMP-2 and -9 in HT 1080 Fibrosarcoma. Int. J. Mol. Sci. 2022, 23, 2660. https:// doi.org/10.3390/ijms23052660

Academic Editor: Eric Huet

Received: 31 January 2022

Accepted: 25 February 2022

Published: 28 February 2022

Publisher's Note: MDPI stays neutral with regard to jurisdictional claims in published maps and institutional affiliations.

Copyright: (c) 2022 by the authors. Licensee MDPI, Basel, Switzerland. This article is an open access article distributed under the terms and conditions of the Creative Commons Attribution (CC BY) license (https:// creativecommons.org/licenses/by/ $4.0 /)$.

\begin{abstract}
A phenyl ethanoid, salidroside (SAL), and two secoiridoids, 8(E)-nuezhenide (NZD) and ligustroside (LIG), were isolated from fruits of Ligustrum japonicum, used as traditional folk medicine, and their chemical structures were elucidated by the comparison of spectral data with published literature. Matrix metalloproteinases (MMPs) are major enzymes that play crucial roles in the metastasis and invasive behavior of tumors. In particular, MMP-2 and MMP-9, regulated by the MAPK signaling pathways, including p38, ERK and JNK, are known to play a key role in the degradation of the basement membrane. In the present study, the effects of SAL, NZD and LIG on the expression of MMP-2 and -9 were examined in phorbol 12-myristate 13-acetate (PMA)-induced HT 1080 cells. All the compounds significantly lowered the amount of MMP-2 and MMP-9 released, as determined by gelatin zymography and ELISA. In addition, the mRNA and protein expression levels of MMP-2 and MMP-9 were significantly suppressed, as measured by RT-PCR and Western blotting. According to the Western blotting assay, SAL and LIG effectively reduced the expression of MMP-2 in a dose-dependent manner. NZD lowered the expression of MMP-9 in a similar way. The phosphorylation of p38, ERK and JNK was also significantly suppressed by these compounds. These findings suggest that all the compounds regulate the release and expression of MMP-2 and MMP-9 via MAPK signaling pathways.
\end{abstract}

Keywords: Ligustrum japonicum fructus; matrix metalloproteinases; MAPK; HT1080

\section{Introduction}

Cancer is a fatal disease in humans, and many efforts have been made to treat it. Tumor progression is a complex multi-step process, involving cell division and growth, proteolysis of the extracellular matrix (ECM), cell migration and angiogenesis [1-3]. The extracellular matrix functions as a structural support for the cells, and plays a major role in cancer metastasis, tissue formation, intercellular communication and gene expression. Matrix metalloproteinases (MMPs) act on the degradation and remodeling of the extracellular matrix, and are also involved in the release of various signaling proteins [4,5]. Among the MMPs in the human body, MMP-2 and MMP-9, which are gelatinases, are known to digest type IV collagen, a major component of the extracellular matrix, and to induce cancer cell invasion and metastasis by participating in both basement membrane degradation and the formation of new blood vessels [6-8]. Therefore, because of the key role that MMPs play in tumorigenesis and metastasis, modulation of MMP expression could be a strategic target for the development of cancer-fighting and therapeutic methods.

Fibrosarcoma is a cancer that affects fibroblasts, which are responsible for making fibrous tissue found throughout the body. The highly tumorigenic HT1080 human fibrosarcoma cell line has been well studied and is widely preferred for studies on oxidative stress, 
inflammation and tumor cell invasion. In addition, HT1080 contains wild-type cancerrelated proteins, which have been reported to be closely linked with inflammation and tumorigenic expressions [9].

Much attention has been given to MMPs over the past few decades. The pathogenesis of many major diseases, such as cardiovascular disease, cancer, inflammation, autoimmune diseases and neurodegenerative diseases, has been shown to be closely related to MMP function [10-12]. Despite considerable research efforts, the early clinical trials for firstgeneration MMP inhibitors have been disappointing, with undesirable side effects and a marked lack of efficacy. Therefore, targeting MMPs in the search for novel therapeutic agents against cancer is of great interest. Studies reported antitumor compounds that act on MMPs, including structure-based compounds, therapeutic antibodies and natural products. Natural products, which not only have structurally diverse chemistries, but have also been used for a long time as an important source of bioactive substances, have received great attention as a template for drug discovery, as well as a probe to investigate biochemical pathways [13-15].

In the course of screening inhibitors for MMP-2 and MMP-9 from natural resources, we found that an extract of Ligustrum japonicum fructus had an MMP inhibitory effect, and we recently reported that two compounds (GL-3 and oleonuezhenide) isolated from it significantly inhibited MMP-2 and MMP-9 [16,17]. In addition to GL-3 and oleonuezhenide, ${ }^{1} \mathrm{H}$ NMR spectral analysis of the chromatographic fractions of the above plant extract showed that structurally related substances were present as minor components in the more polar fraction. Further separation on this polar fraction gave one phenylethanoid glycoside and two secoiridoid glycosides. In the current study, we report the isolation of salidroside (SAL), 8(E)-nuezhenide (NZD) and ligustroside (LIG), and their effects on the activation and expression of MMP-2 and MMP-9 in the HT1080 human fibrosarcoma cell line.

\section{Results and Discussion}

\subsection{Structure Elucidation}

The phenylethanoid, SAL, and the iridoids, NZD and LIG, were isolated from Ligustrum japonicum fructus (Figure 1). The chemical structures were elucidated and verified by 2D NMR spectroscopy, and by comparing the NMR spectral data with those previously published in the literature [18-21]. The $1 \mathrm{H}$ and 13C NMR spectral data of the isolated compounds were in accordance with the values found in the literature for the same compounds (Supplementary Materials).
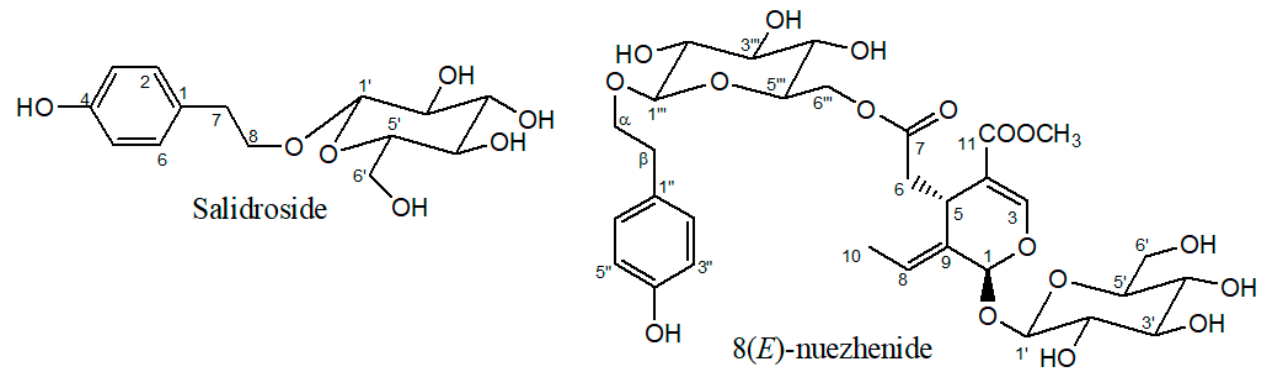

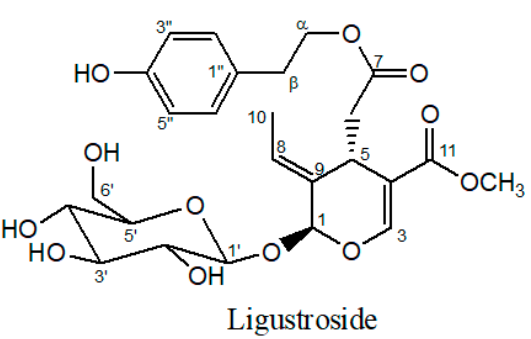

Figure 1. Chemical structures of isolated compounds salidroside (SAL), 8(E)-nuezhenide (NZD) and ligustroside (LIG).

\subsection{Cytotoxicity of the Isolated Compounds}

Before the in vitro assays using the isolated compounds, their cytotoxicity in HT1080 cells was evaluated with the traditional 3-(4, 5-dimethylthiazol-2-yl)-2, 5-diphenyltetrazolium bromide (MTT) assay (Figure 2), with three different concentrations of 10, 50 and $100 \mu \mathrm{M}$. The survival rate of the HT1080 cells for all the compounds was over $80 \%$ at less than $100 \mu \mathrm{M}$, compared with the untreated control. These findings revealed that the tested samples were biocompatible with concentrations below $100 \mu \mathrm{M}$ (Figure 2). 
(a)

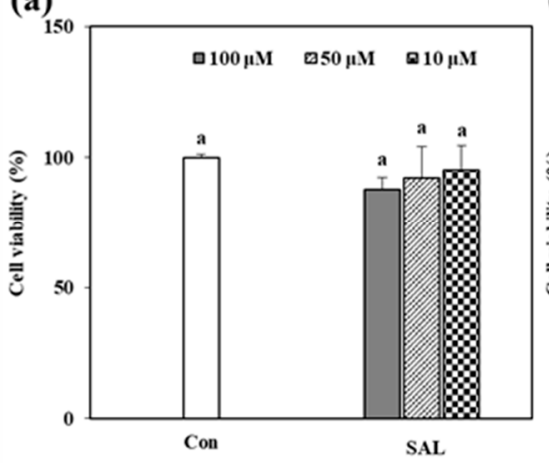

(b)

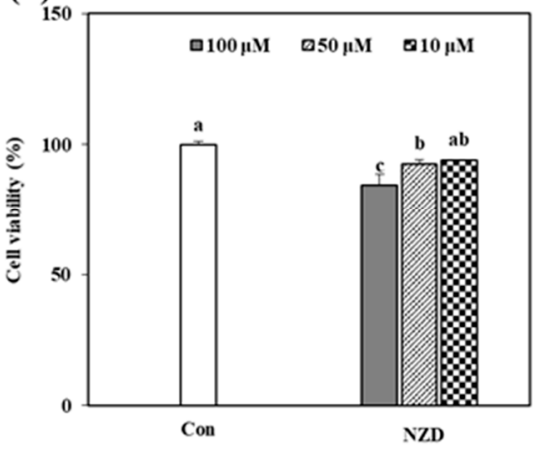

(c)

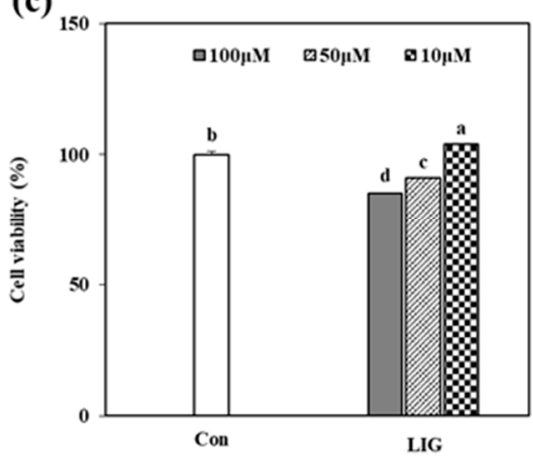

Figure 2. Effect of SAL (a), NZD (b) and LIG (c) on viability of HT1080 cells. The data are presented as mean \pm standard deviation of three independent experiments for each compound (Con: untreated cells). ${ }^{\text {a-d }}$ Means with different letters indicate statistically significant difference at $p<0.05$ level, as assessed by Duncan's multiple range test.

\subsection{Effect of SAL, NZD and LIG on Enzymatic Activity of MMP-2 and MMP-9}

The protein levels of active MMPs released by PMA-stimulated HT1080 cells, treated with or without SAL, NZD and LIG, were assessed based on enzymatic activity using the gelatin zymography assay. SAL and LIG significantly suppressed the levels of MMP-2 and MMP-9, as shown in Figure 3, but not in a dose-dependent manner. Furthermore, NZD showed the weakest inhibition effect against MMP-2 at $100 \mu \mathrm{M}$, but was even less effective in inhibiting MMP-9.
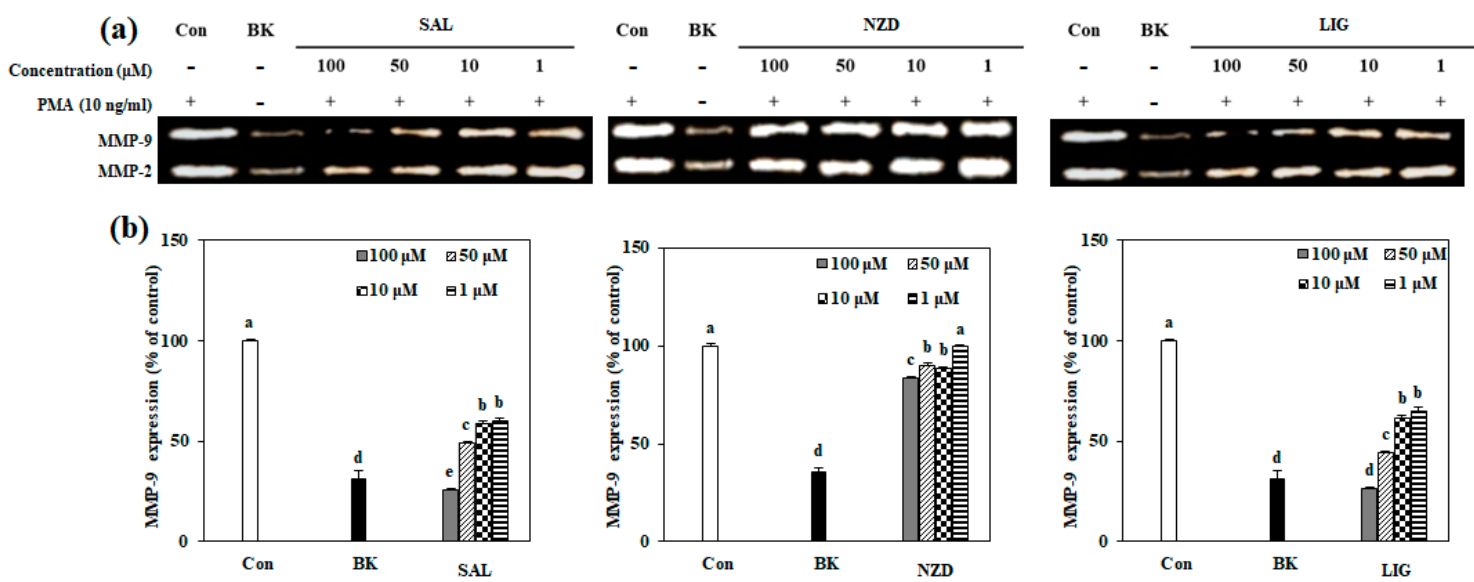

(b)
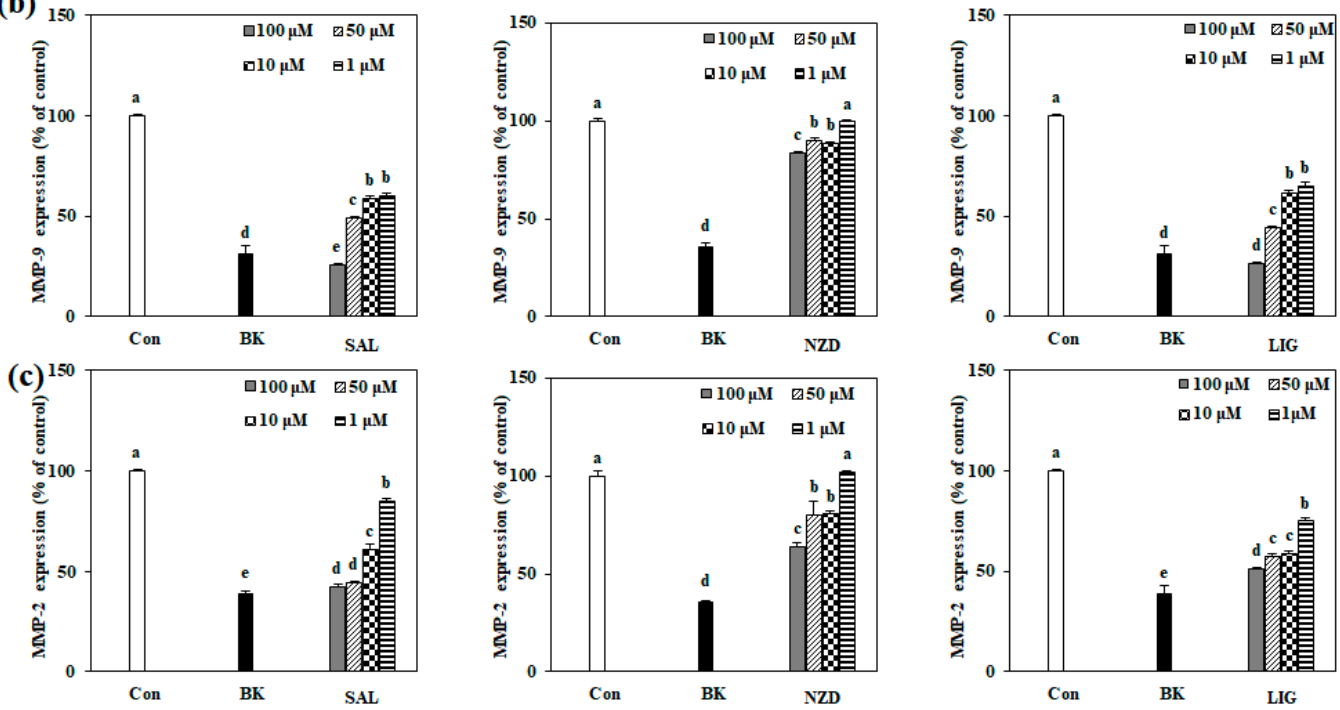

Figure 3. Effects of SAL, NZD and LIG on the levels of MMP-9 and MMP-2, evaluated by gelatin zymography in HT1080 cells (Con: untreated PMA-stimulated cells; BK: untreated unstimulated cells). (a) Gelatinolytic activities of MMP-9 and MMP-2 on gelatin containing $10 \%$ polyacrylamide gel. White areas in gelatin zymography, which represent digestion by active MMP-9 (b) and MMP-2 (c), were quantified by densitometry. Control and blank were without treated samples and blank was also without PMA. ${ }^{\mathrm{a}-\mathrm{e}}$ Means with different letters at the same concentration are significantly different $(p<0.05)$, as assessed by Duncan's multiple range test. 
MMP-specific ELISA assays were performed to more clearly confirm the inhibitory effects of the compounds on the secretion of MMP-2 and MMP-9 into the cell culture media. In this case, unlike gelatin zymography, all the compounds showed strong inhibitory effects against MMP-2 and MMP-9, as shown in Figure 4; SAL, NZD and LIG, at a concentration of $100 \mu \mathrm{M}$, reduced the amount of MMP-9 to 383.3, 53.3 and $13.4 \mathrm{pq} / \mathrm{mL}$, respectively, from $2888.6 \mathrm{pg} / \mathrm{mL}$ released by PMA stimulation only. Among the compounds, SAL exhibited the strongest inhibitory effect on MMP-9, which reduced the secretion of MMP-9 to $715.7 \mathrm{pg} / \mathrm{mL}$, even at $10 \mu \mathrm{M}$. For MMP-2, all the compounds showed a greater reduction effect than for MMP-9, using the ELISA assay. SAL, NZD and LIG reduced the release of MMP-2 to 1.4, 2.6 and $2.0 \mathrm{ng} / \mathrm{mL}$, respectively, lower than $4.6 \mathrm{ng} / \mathrm{mL}$ in the untreated blank cell, from $18.7 \mathrm{ng} / \mathrm{mL}$ after PMA stimulation at a concentration of $10 \mu \mathrm{M}$. The inhibition of MMP-2 and MMP-9 released into the cell culture was not concentration dependent. The secretions of MMP-9 at a $50 \mu \mathrm{M}$ concentration of SAL, NZD and LIG were reduced to $11.4 \%, 18.3 \%$ and $13.9 \%$, respectively, compared to the control. The secretions of MMP-2 were reduced to $17.5 \%, 14.0 \%$ and $10.7 \%$, respectively, even at $10 \mu \mathrm{M}$. The $\mathrm{IC}_{50}$ of these compounds was expected to be comparable to doxycycline (Periostat), the (FDA)-approved MMP inhibitor for periodontal disease treatment, reported in the literature [12,22].
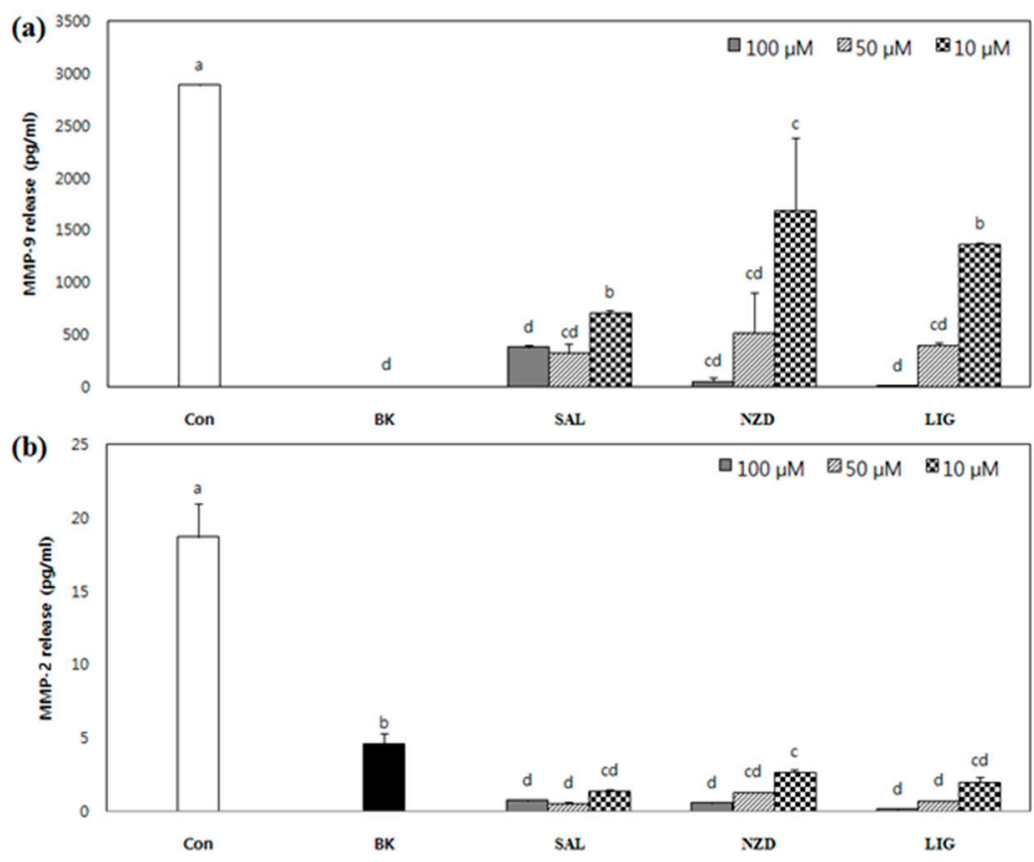

Figure 4. Released amounts of MMP-9 (a) and MMP-2 (b) by PMA-stimulated HT1080 cells treated with or without SAL, NZD and LIG at given concentrations (Con: untreated PMA-stimulated cells; BK: untreated unstimulated cells). The culture medium was collected and analyzed for the MMP-2 and -9 levels by ELISA. Data are mean \pm SD of three replicates $(n=3) .{ }^{\text {a-e }}$ Means with different letters at the same concentration are significantly different $(p<0.05)$, as assessed by Duncan's multiple range test.

\subsection{Effect of SAL, NZD and LIG on $m R N A$ and Protein Expressions of MMP-2 and MMP-9}

In order to investigate the inhibitory mechanisms of all the compounds against the gelatinolytic activity of MMP-2 and MMP-9, the mRNA and total protein expression levels of MMP-2 and MMP-9 were evaluated by RT-PCR and immunoblotting (Figure 5). Contrary to the results obtained by gelatin zymography, when all the compounds were treated at a concentration of $100 \mu \mathrm{M}$, the mRNA expression of MMP-2 and MMP-9 was reduced to a level similar to that of the blank cell, not stimulated with PMA, indicating that they inhibit the expression of MMP-2 and -9 at the nuclear level (Figure 5a,b). A significant inhibitory effect of the compounds was also observed on the protein expression of MMP-2 and MMP-9. For MMP-9, SAL showed a protein expression level of $16.7 \%$, lower than that 
of BK (23.4\%), compared to the control, at a concentration of $100 \mu \mathrm{M}$, but for MMP-2, it exhibited expression levels of 35.5, 34.1 and $22.6 \%$, similar to, or lower than, BK (35.3\%) at 10,50 and $100 \mu \mathrm{M}$ concentrations, respectively (GAPDH was used as an internal standard for quantification). In contrast to SAL, NZD showed a lower protein expression pattern for MMP-9 than for MMP-2. For MMP-9, at concentrations of 10, 50 and $100 \mu \mathrm{M}$, NZD showed protein expression levels of $24.8,15.1$ and $11.5 \%$, respectively, quite similar to that of BK (16.8\%), and for MMP-2, a protein expression level of 50.5\% (BK 35.3\%) at $100 \mu \mathrm{M}$ was shown. In the case of treatment with LIG, MMP-9 protein expression was only significantly suppressed at a concentration of $100 \mu \mathrm{M}$, and a $49.1 \%$ expression level (BK 23.4\%) was observed. MMP-2 protein expression was effectively suppressed at all the treated concentrations of LIG, in a dose-dependent manner, showing expression levels of $57.2,32.9,20.2$ and $15.3 \%$ at concentrations of 1,10, 50 and $100 \mu \mathrm{M}$, respectively (Figure 5c,d).
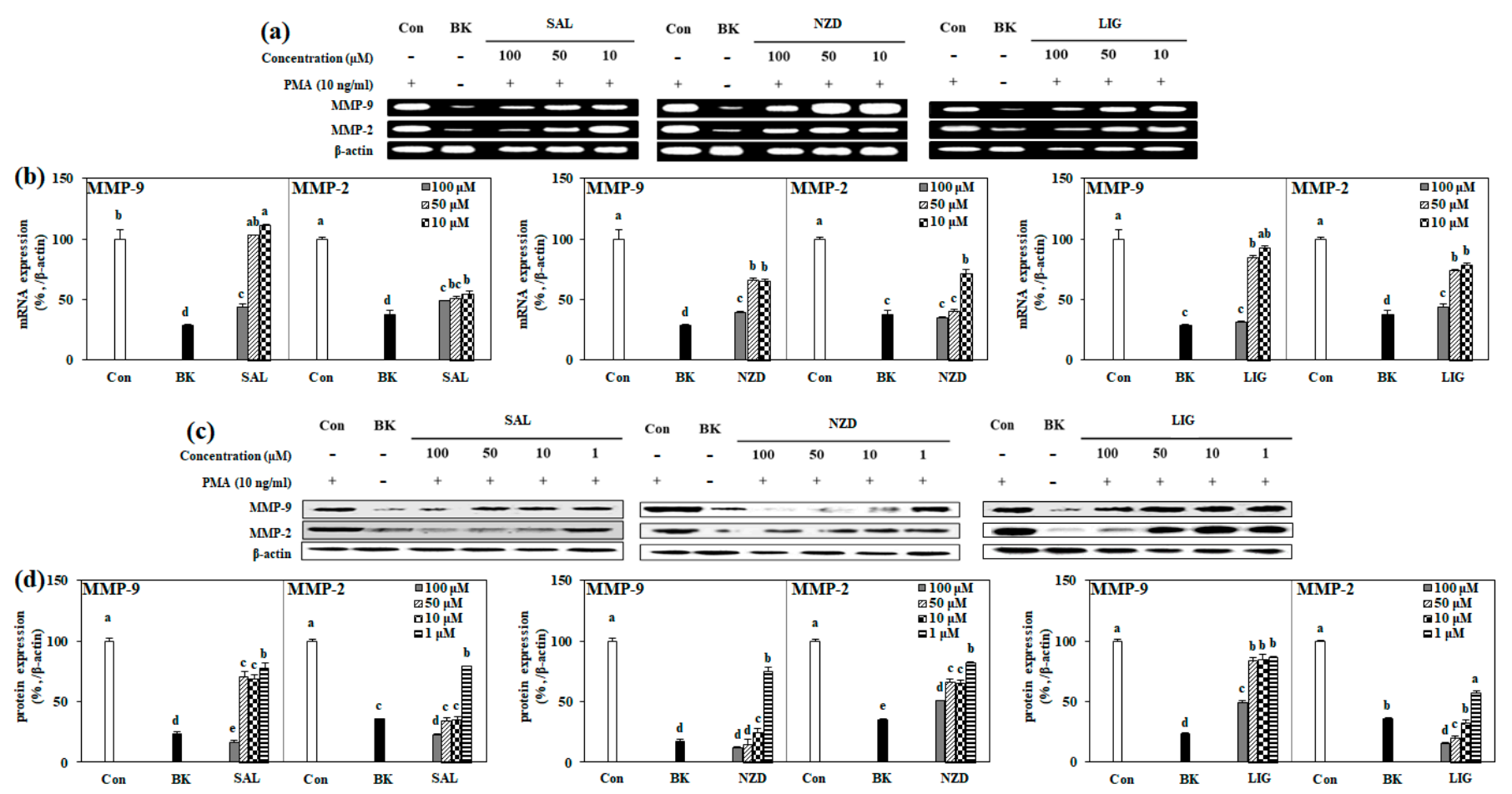

Figure 5. Effects of SAL, NZD and LIG on mRNA $(\mathbf{a}, \mathbf{b})$ and protein $(\mathbf{c}, \mathbf{d})$ expression levels of MMP-9 and MMP-2, analyzed by RT-PCR and immunoblotting in HT1080 cells, respectively (Con: untreated PMA-stimulated cells; BK: untreated unstimulated cells). $\beta$-actin was used as the loading control. HT1080 cells were treated with compounds prior to stimulation with PMA. The mRNA and protein expression levels of MMP-9 and MMP-2 were densiometrically calculated and given as a relative percentage of the stimulated untreated control group (Con). Expression levels were normalized against housekeeping control, $\beta$-actin. ${ }^{\text {a-e }}$ Means with different letters at the same concentration are significantly different $(p<0.05)$, as assessed by Duncan's multiple range test.

\subsection{Effect of SAL, NZD and LIG on MAPK Signaling Pathway}

It is known that activation of the mitogen-activated protein kinase (MAPK) pathway is part of the regulation of tumor metastasis, and suppression of its activation is closely related to the downregulation of MMP expression [23-26]. The phosphorylation of MAPKassociated proteins, i.e., p38, p-ERK and p-JNK, was evaluated to elucidate the mechanisms of the intracellular pathways involved in MMP inhibition. As expected, PMA stimulation resulted in increased expression of phosphorylated ERK, JNK and p-38, in association with increased cellular activity. Activation of the MAPK pathway, stimulated by PMA, is shown in Figure 6. The phosphorylation level of the MAPK pathway was measured by the amount of protein expressed in the Western blotting assay. All the compounds significantly 
attenuated the protein expressions of p-p38, p-ERK and p-JNK, when compared to the control, at concentrations of more than $50 \mu \mathrm{M}$. In particular, SAL and LIG showed $47.2 \%$ and $57.5 \%$ expression levels of p-JNK, respectively, even at a concentration of $1 \mu \mathrm{M}$, and NZD showed an expression level of $28.7 \%$ of p38 at the same concentration (Figure $6 a, b$ ). Hence, it could be suggested that the expression levels of MMP-2 and -9 were suppressed by the downregulation of p-ERK, p-JNK and p-p38 MAPK-mediated pathways. The results matched well with the mRNA and protein expressions of MMP-2 and MMP-9.

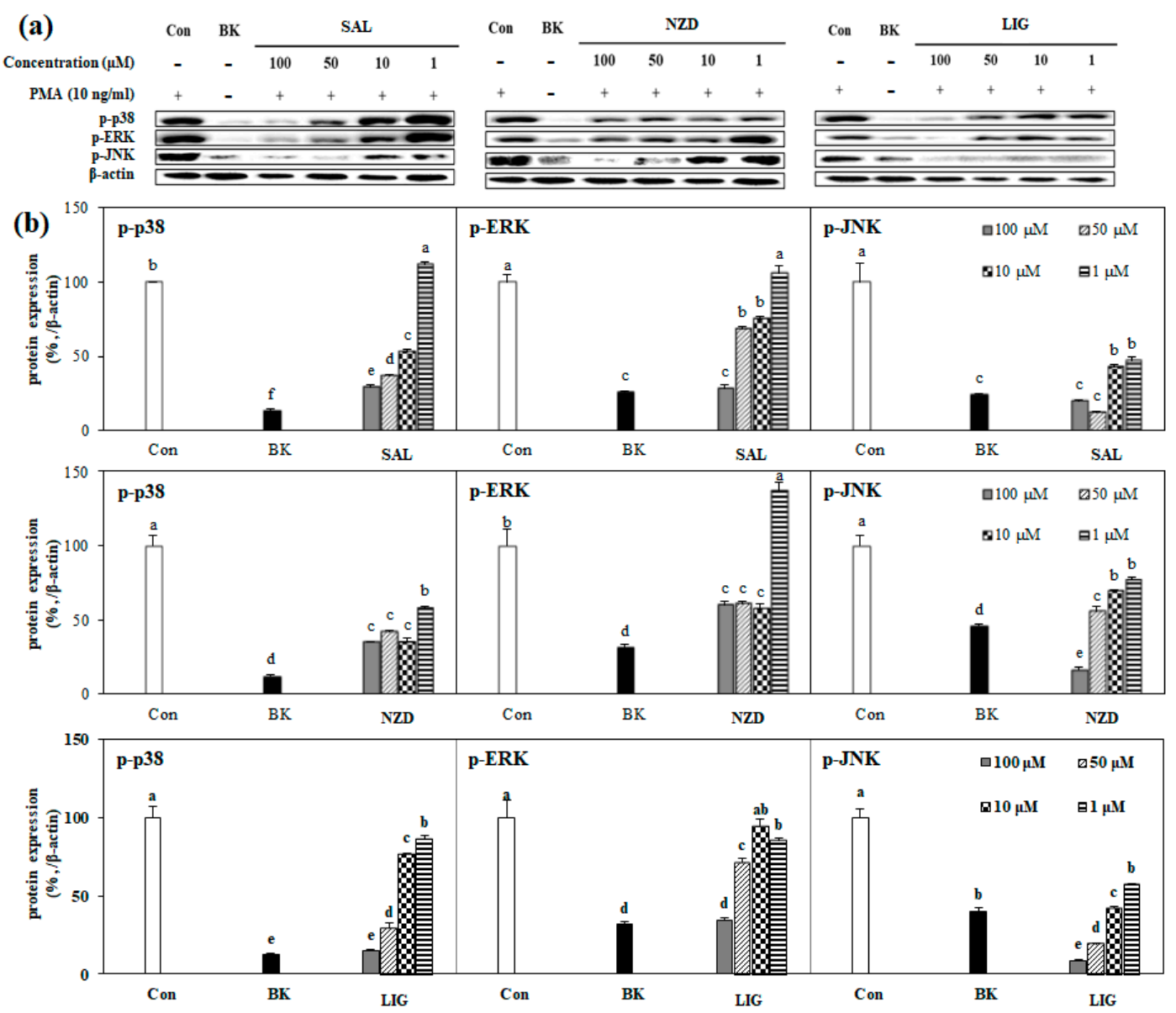

Figure 6. (a) Effects of SAL, NZD and LIG on protein levels of phosphorylated (p-) p38, ERK and JNK by Western blot in HT1080 cells (Con: untreated PMA-stimulated cells; BK: untreated unstimulated cells). $\beta$-actin was used as the loading control. The MMP production in cells was stimulated with phorbol 12-myristate 13-acetate (PMA), and cells were subjected to treatment with isolated compounds. The phosphorylated protein levels were densiometrically (b) calculated from band images and given as relative percentage of PMA-stimulated untreated control group (Con). Expression levels were normalized against house-keeping control, $\beta$-actin. ${ }^{a-e}$ Means with different letters at the same concentration are significantly different $(p<0.05)$, as assessed by Duncan's multiple range test.

MMP-2 and MMP-9 are proteolytic enzymes that degrade the extracellular matrix; they are closely related to the metastasis and invasion of tumors, and have long been regarded as attractive targets for the development of cancer therapeutics [27-29]. However, since most synthetic MMP inhibitors are toxic, the need for the development of more selective and newer pharmacophores of MMP inhibitors, without side effects, has been raised $[12,14]$. Natural plant extracts and their phytochemicals are recognized as promising and rich sources for achieving chemoprevention that reduces the morbidity and mortality of cancer patients, as well as for discovering novel lead structures with inhibitory activity against MMPs $[13,15]$. 
SAL, previously isolated from several plants, is a member of the phenylethanoid glycoside class. It has been reported to show a variety of bioactivities, such as antibacterial, anticancer, anti-inflammatory and anti-fertility. In this study, a remarkable decrease in MMP-2 and -9 activity by SAL was observed in HT1080 cells. The inhibitory effect of MMP-2 and -9 activity by SAL was previously measured in human lung cancer cells (A549) and human bladder cancer cells (T24), respectively, and a significant decrease in activity has been reported [30,31]. In a study by Sun et al. [32], SAL was also shown to increase the tissue inhibitor of metalloproteinase-2 (TIMP-2), which is a crucial regulator of MMP-2 and MMP-9 activation. It was reported that salidroside treatment increased TIMP-2 levels in conditioned medium of HT1080 cells. The effect of SAL on the TIMP-2 levels might be credited for the differences between gelatin zymography and ELISA assays, where the former detects both pro and active enzymes. Although MAPK suppression was suggested as the mechanism for suppressing MMP expression, its effect on the TIMP-2 levels hints at a concurrent mechanism to hinder MMP activity.

Iridoid glycosides are monoterpenoid glycosides with a characteristic cyclopentanopyran part. The cleavage of the bond between C-7 and C-8 in the cyclopentane ring of iridoids leads to secoiridoids having carboxylic acid and olefin moieties. A number of biological activities have been published for secoiridoid glycosides, including antioxidant, anti-diabetic, anti-inflammatory, immunomodulatory, neuroprotective and anti-cancer effects [33]. As already described, NZD and LIG showed significant inhibitory effects on the enzymatic activity of MMP-2 and -9. Two previous studies reported that secoiridoid glycosides suppressed MMP enzymes [34,35], but, with the exception of GL-3 and oleonuezhenide reported by our group, there have been no reports on the inhibitory activity of secoiridoid glycosides against MMP-2 and -9 in actual experiments [15]. According to the literature, the MMP-9 inhibitory effect of secoiridoid glycosides was calculated by molecular docking, through computer simulations. The computational molecular docking analysis revealed that LIG was effective in preventing MMP-1, MMP-3 and MMP-9 activities [35]. The possible inhibition of the direct enzymatic activity of MMPs further suggests a concurrent mechanism for LIG and NZD, aside from MAPK suppression, similar to SAL and its effect on TIMPs. This might explain the differences that were observed in the gelatin zymography and expression assays, in terms of effectiveness, between the compounds. In this context, future studies focusing on the effects of these compounds on TIMP levels and direct enzymatic activity would provide invaluable inputs regarding the potential of SAL, NZD and LIG as antitumor agents.

\section{Materials and Methods}

\subsection{Apparatus and Reagents}

The ${ }^{1} \mathrm{H}$ and ${ }^{13} \mathrm{C}$ NMR spectra were recorded on a Varian NMR 300 spectrometer (300 MHz for ${ }^{1} \mathrm{H}$ and $75.5 \mathrm{MHz}$ for ${ }^{13} \mathrm{C}$ ). Chemical shifts ( $\delta$ in ppm) were referenced to the residual solvent peak. The NMR solvent used was $\mathrm{CD}_{3} \mathrm{OD}$ (Cambridge Isotope Laboratories, Inc., Cambridge, MA, USA, deuterium degree 99.95\%). Mass spectroscopic data were obtained using high-resolution ESI mass spectrometer at the Korean Basic Science Institute (Center of Research Equipment, Ochang, Chungbuk, Korea). High-performance liquid chromatography (HPLC) was performed with a Dionex P580 equipped with Varian 350 RI detector using a column (YMC pack ODS-A, $250 \times 10 \mathrm{~mm}, \mathrm{~S} 5 \mu \mathrm{M}, 12 \mathrm{~mm}$ ) and a guard column $(7.5 \times 4.6 \mathrm{~mm}$, Alltech). All solvents used were of spectral grade or were distilled from the glass before use.

\subsection{Extraction, Fractionation and Isolation}

The air-dried samples of Ligustrum japonicum fructus were purchased from an online market (Omniherb Company, Daegu, Korea) in 2014. The fruits were extracted twice for $24 \mathrm{~h}$ using dichloromethane, and then further extracted twice using methanol $(\mathrm{MeOH})$. The crude extracts obtained through dichloromethane and $\mathrm{MeOH}$ were combined (197.6 g), and the combined extracts were partitioned between methylene chloride and water $\left(\mathrm{H}_{2} \mathrm{O}\right)$. The 
methylene chloride layer was further partitioned between $n$-hexane and $85 \%$ aq.MeOH, and the water layer was also further partitioned between $n$-butanol $(n-\mathrm{BuOH})$ and $\mathrm{H}_{2} \mathrm{O}$. These four solvent fractions were concentrated on a rotary evaporator to give $n$-hexane (56.1 g), $85 \%$ aq. $\mathrm{MeOH}(46.3 \mathrm{~g}), n-\mathrm{BuOH}(33.0 \mathrm{~g})$ and $\mathrm{H}_{2} \mathrm{O}(51.5 \mathrm{~g})$, respectively. A portion of the $n$ $\mathrm{BuOH}$ (10.0 g) fraction was chromatographed onto a $\mathrm{C}_{18}$ silica gel with $\mathrm{MeOH}-\mathrm{H}_{2} \mathrm{O}$ solvent gradient in decreasing polarity (50, 60, 70, 80, 90\% aq. $\mathrm{MeOH}$, and 100\% $\mathrm{MeOH})$. Fraction 2 (60\% aq. $\mathrm{MeOH}, 2.93 \mathrm{~g})$ was further chromatographed by HP20 column chromatography to give 5 fractions $\left(100 \% \mathrm{H}_{2} \mathrm{O}, 50 \%\right.$ aq. $\mathrm{MeOH}, 50 \%$ aq.acetone, $100 \% \mathrm{MeOH}$ and $100 \%$ acetone), named as HP1 to HP5, respectively. The HP2 (50\% aq.MeOH, $0.532 \mathrm{~g}$ ) fraction was separated by reversed phase HPLC (ODS-A, 20\% aq.MeOH) to afford SAL (7.8 mg), NZD (7.9 mg) and LIG (5.6 mg).

Salidroside (SAL): ${ }^{1} \mathrm{H}$ NMR (300 MHz, CD $\left.\mathrm{OD}\right) \delta 6.95(2 \mathrm{H}, \mathrm{H}-2 /-6), 6.68(2 \mathrm{H}, \mathrm{H}-3 /-5)$, $5.03\left(1 \mathrm{H}, \mathrm{H}-1^{\prime}\right), 3.70 \sim 3.79\left(5 \mathrm{H}, \mathrm{H}-8 /-2^{\prime} /-5^{\prime} /-6^{\prime}\right), 3.54\left(1 \mathrm{H}, \mathrm{H}-6^{\prime}\right), 3.49\left(1 \mathrm{H}, \mathrm{H}-3^{\prime}\right), 3.40(1 \mathrm{H}$, $\left.\mathrm{H}-4^{\prime}\right), 2.72(2 \mathrm{H}, \mathrm{H}-7) ;{ }^{13} \mathrm{C}$ NMR $\left(75 \mathrm{MHz}, \mathrm{CD}_{3} \mathrm{OD}\right) \delta 156.6$ (C-4), 130.8 (C-2/-6), 130.5 (C-1), $116.0(\mathrm{C}-3 /-5), 104.3\left(\mathrm{C}-1^{\prime}\right), 78.0\left(\mathrm{C}-5^{\prime}\right), 77.9\left(\mathrm{C}-3^{\prime}\right), 75.0\left(\mathrm{C}-2^{\prime}\right), 72.1(\mathrm{C}-8), 71.6\left(\mathrm{C}-4^{\prime}\right), 62.7$ $\left(\mathrm{C}-6^{\prime}\right), 36.4(\mathrm{C}-7)$; ESI-MS (positive-ion mode) $\mathrm{m} / \mathrm{z}$ : $301[\mathrm{M}+\mathrm{H}]^{+}$.

8(E)-nuezhenide (NZD): ${ }^{1} \mathrm{H}$ NMR (300 MHz, CD $\left.3 \mathrm{OD}\right) \delta 7.15(1 \mathrm{H}, \mathrm{H}-3), 6.95$ (2H, H$\left.2^{\prime \prime} /-6^{\prime \prime}\right), 6.68\left(2 \mathrm{H}, \mathrm{H}-3^{\prime \prime} /-5^{\prime \prime}\right), 5.36(1 \mathrm{H}, \mathrm{H}-8), 5.03\left(2 \mathrm{H}, \mathrm{H}-1^{\prime} /-1^{\prime \prime \prime}\right) 4.34\left(1 \mathrm{H}, \mathrm{H}-4^{\prime \prime \prime}\right), 4.27(1 \mathrm{H}$, $\left.\mathrm{H}-5^{\prime \prime \prime}\right), 4.09\left(1 \mathrm{H}, \mathrm{H}-4^{\prime \prime \prime}\right), 3.73 \sim 3.79\left(3 \mathrm{H}, \mathrm{H}-3^{\prime} /-5^{\prime} /-2^{\prime \prime \prime}\right), 3.76\left(3 \mathrm{H}, \mathrm{H}-11-\mathrm{COOCH}_{3}\right), 3.70(1 \mathrm{H}$, $\mathrm{H}-\alpha), 3.54\left(2 \mathrm{H}, \mathrm{H}-6^{\prime}\right), 3.49\left(3 \mathrm{H}, \mathrm{H}-5 /-3^{\prime} /-3^{\prime \prime \prime}\right), 3.40\left(2 \mathrm{H}, \mathrm{H}-4^{\prime} /-4^{\prime \prime \prime}\right), 2.72(2 \mathrm{H}, \mathrm{H}-\beta), 2.41(2 \mathrm{H}$, $\mathrm{H}-6), 1.71(3 \mathrm{H}, \mathrm{H}-10) ;{ }^{13} \mathrm{C}$ NMR (75 MHz, CD $\left.\mathrm{OD}\right) \delta 172.8$ (C-7), 168.5 (C-11), $156.6\left(\mathrm{C}-4^{\prime \prime}\right)$, $155.0(\mathrm{C}-3), 130.8\left(\mathrm{C}-2^{\prime \prime} /-6^{\prime \prime}\right), 130.5\left(\mathrm{C}-1^{\prime \prime}\right), 130.3(\mathrm{C}-9), 124.8(\mathrm{C}-8), 116.0\left(\mathrm{C}-3^{\prime \prime} /-5^{\prime \prime}\right), 104.3$ $\left(\mathrm{C}-1^{\prime \prime \prime}\right), 100.7\left(\mathrm{C}-1^{\prime}\right), 95.0(\mathrm{C}-1), 78.4\left(\mathrm{C}-5^{\prime}\right), 77.9\left(\mathrm{C}-3^{\prime \prime \prime}\right), 77.8\left(\mathrm{C}-3^{\prime}\right), 75.1\left(\mathrm{C}-5^{\prime \prime \prime}\right), 74.9\left(\mathrm{C}-2^{\prime \prime \prime}\right)$, $74.7\left(\mathrm{C}-2^{\prime}\right), 72.2(\mathrm{C}-\alpha), 71.5\left(\mathrm{C}-4^{\prime \prime \prime}\right), 71.4\left(\mathrm{C}-4^{\prime}\right), 65.0\left(\mathrm{C}-6^{\prime \prime \prime}\right), 62.7\left(\mathrm{C}-6^{\prime}\right), 52.0\left(\mathrm{C}-11-\mathrm{COOCH}_{3}\right)$, 41.3 (C-6), 36.4 (C- $\beta$ ), 31.8 (C-5), 13.8 (C-10); ESI-MS (positive-ion mode) m/z: 687 [M+H] $]^{+}$

Ligustroside (LIG): ${ }^{1} \mathrm{H}$ NMR (300 MHz, CD $\left.3 \mathrm{OD}\right) \delta 7.15(1 \mathrm{H}, \mathrm{H}-3), 6.95\left(2 \mathrm{H}, \mathrm{H}-2^{\prime \prime} /-6^{\prime \prime}\right)$, $6.68\left(2 \mathrm{H}, \mathrm{H}-3^{\prime \prime} /-5^{\prime \prime}\right), 5.53(1 \mathrm{H}, \mathrm{H}-1) 5.36(1 \mathrm{H}, \mathrm{H}-8), 5.03\left(1 \mathrm{H}, \mathrm{H}-1^{\prime}\right), 4.41(2 \mathrm{H}, \mathrm{H}-\alpha), 3.76$ $\left(3 \mathrm{H}, \mathrm{H}-11-\mathrm{COOCH}_{3}\right), 3.40 \sim 3.79\left(6 \mathrm{H}, \mathrm{H}-5 /-2^{\prime} /-3^{\prime} /-4^{\prime} /-5^{\prime} /-6^{\prime}\right), 2.83(2 \mathrm{H}, \mathrm{H}-\beta), 2.41(2 \mathrm{H}$, $\mathrm{H}-6), 1.72$ (3H, H-10); ${ }^{13} \mathrm{C}$ NMR (75 MHz, CD $\left.\mathrm{OD}\right) \delta 173.0$ (C-7), $168.4(\mathrm{C}-11), 156.9\left(\mathrm{C}-4^{\prime \prime}\right)$, 154.9 (C-3), $130.9\left(\mathrm{C}-2^{\prime \prime} /-6^{\prime \prime}\right), 130.0(\mathrm{C}-9), 129.9\left(\mathrm{C}-1^{\prime \prime}\right), 124.7(\mathrm{C}-8), 116.1\left(\mathrm{C}-3^{\prime \prime} /-5^{\prime \prime}\right), 100.7$ $\left(\mathrm{C}-1^{\prime}\right), 95.0(\mathrm{C}-1), 78.4\left(\mathrm{C}-5^{\prime}\right), 77.9\left(\mathrm{C}-3^{\prime}\right), 74.7\left(\mathrm{C}-2^{\prime}\right), 71.4\left(\mathrm{C}-4^{\prime}\right), 66.9(\mathrm{C}-\alpha), 62.7\left(\mathrm{C}-6^{\prime}\right), 51.9$ $\left(\mathrm{C}-11-\mathrm{COOCH}_{3}\right), 41.2$ (C-6), 35.2 (C- $\beta$ ), 31.9 (C-5), 13.6 (C-10); ESI-MS (positive-ion mode) $m / z: 525[\mathrm{M}+\mathrm{H}]^{+}$.

\subsection{Cell Maintenance and Determination of Cytotoxicity}

Human fibrosarcoma cell line, HT1080, was adopted from KCLB (Korea Cell Line Bank, Jongro, Seoul, Korea), and cultured in T-75 flasks (SPL, Pocheon, Gyeonggi, Korea) in $5 \% \mathrm{CO}_{2}$ and at $37^{\circ} \mathrm{C}$ in a humidified incubating condition, and the medium used was RPMI 1640 (GenDEPOT, Baker, TX, USA) with 10\% fetal bovine serum (FBS) (GenDEPOT, Baker, TX, USA) and 100 unit/mL penicillin-streptomycin (Gibco-BRL, Grand Island, NY, USA). The cell lines were washed with PBS buffer (Gibco-BRL, Grand Island, NY, USA) and the medium was changed six times a week.

For cell viability assay, cell lines were transferred to 96 -well plates at $5 \times 10^{3}$ cells /well density. After their transfer, cells were cultured for $24 \mathrm{~h}$ and their medium was changed with fresh medium, which was followed by the treatment with samples (100, 50 and $10 \mu \mathrm{M})$. Cells were re-supplied with fresh medium after $24 \mathrm{~h}$ of incubation and treated with $100 \mu \mathrm{L}$ of MTT solution $(1 \mathrm{mg} / \mathrm{mL})$, and further incubated for $4 \mathrm{~h}$. Finally, the wells were aspirated and introduced into $100 \mu \mathrm{L}$ of dimethyl sulfoxide (DMSO), in order to solubilize the formazan crystals for the measurement by a Victor3 reader (PerkinElmer, Waltham, MA, USA) at $540 \mathrm{~nm}$ optical density.

\subsection{Determination of Active MMP-2 and MMP-9 Levels by Gelatin Zymography}

The protein levels of active MMP-9 and MMP-2 secreted from the HT1080 cells were evaluated by gelatin zymography. Cells were transferred to 24 -well plates at $2 \times 10^{5}$ cells $/$ well 
density. The cells were cultured for $24 \mathrm{~h}$, and, following this, the medium was replaced with serum-free medium. Next, the cells were treated with samples at different concentrations. After $1 \mathrm{~h}$, phorbol 12-myristate 13-acetate (PMA, $10 \mathrm{ng} / \mathrm{mL}$ ) was added to each well, in order to stimulate MMP expression, and cells were further incubated for $24 \mathrm{~h}$. The culture supernatant was harvested, and total protein content of the culture supernatant was evaluated by Bradford protein assay. Conditioned supernatants with the same amount of protein were loaded onto $10 \%$ sodium dodecyl sulfate-polyacrylamide gel containing $1.5 \mathrm{mg} / \mathrm{mL}$ gelatin (Sigma Aldrich, St. Louis, MO, USA). Electrophoresis was conducted under non-reducing conditions. Polyacrylamide gels were washed by buffer $(2.5 \%$ Triton $\mathrm{X}$ 100 (JUNSEI, Japan), $50 \mathrm{mM}$ Tris- $\mathrm{HCl}$, pH 7.5) for $30 \mathrm{~min}$ to remove sodium dodecyl sulfate. Then, gels were kept in developing buffer $\left(10 \mathrm{mM} \mathrm{CaCl}_{2}, 50 \mathrm{mM}\right.$ Tris- $\left.\mathrm{HCl}, 150 \mathrm{mM} \mathrm{NaCl}\right)$ to promote the digestive activity of MMPs on gelatin. Clear zones of gelatin hydrolyzation by MMPs were observed against the Coomassie blue-stained background obtained via incubation in staining buffer (Biosesang, Seongnam, Gyeonggi, Korea). The clear zones were imaged with CAS-400SM Davinch-Chemiimager ${ }^{\mathrm{TM}}$ (Davinch-K, Geumcheon, Seoul, Korea).

\subsection{Enzyme-Linked Immunosorbent Assay (ELISA) for the Detection of MMP-2 and MMP-9 Release}

For the detection of MMP-2 and MMP-9 levels in the HT1080 culture medium, the cells were cultured in 6-well plates and incubated for $24 \mathrm{~h}$, washed with PBS, and then stimulated with PMA. Thereafter, cells were incubated for $24 \mathrm{~h}$ in the presence or absence of the sample. MMP-2 and MMP-9 proteins secreted into the culture supernatant were detected with an ELISA kit (R\&D systems, Inc., Minneapolis, MN, USA) according to the manufacturer's instructions.

\subsection{RNA Extraction and Reverse Transcription Polymerase Chain Reaction (RT-PCR) Analysis}

Whole RNA from HT1080 cell lines was isolated by Trizol reagent (Invitrogen Co., Waltham, MA, USA). Isolated RNA ( $2 \mu \mathrm{g})$ was added to RNase-free water and oligo dT, denatured at $70{ }^{\circ} \mathrm{C}$ for $5 \mathrm{~min}$ and cooled at $4{ }^{\circ} \mathrm{C}$ immediately. In addition, RNA was reverse transcribed in mixtures containing $1 \mathrm{X}$ RT buffer, $1 \mathrm{mM}$ dNTP, 500 ng oligo dT, $140 \mathrm{U}$ M-MLV reverse transcriptase and $40 \mathrm{U}$ RNase inhibitor at $42{ }^{\circ} \mathrm{C}$ for $1 \mathrm{~h}$ and at $72{ }^{\circ} \mathrm{C}$ for $5 \mathrm{~min}$, using thermal cycler (Bio-rad, USA). Each target DNA was amplified by the following sense and antisense primers: forward $5^{\prime}$-TGA-AGG-TCG-GTG-TGA-ACG-GA-3' and reverse $5^{\prime}$-CAT-GTA-GCC-ATG-AGG-TCC-ACC-AC-3' for MMP-2; forward 5'-CACTGT-CCA-CCC-CTC-AGAGC- $3^{\prime}$ and reverse $5^{\prime}$-CAC-TTG-TCG-GCG-ATA-AGG-3 ${ }^{\prime}$ for MMP-9; forward 5'-GCC-ACC-CAG-AAG-ACT-GTG-GAT-3' and reverse 5'-TGG-TCCAGG-GTT-TCT-TAC-TCC- $3^{\prime}$ for $\beta$-actin. Target DNA amplification cycles were performed at $95{ }^{\circ} \mathrm{C}$ for $45 \mathrm{~s}, 60{ }^{\circ} \mathrm{C}$ for $1 \mathrm{~min}$ and $72{ }^{\circ} \mathrm{C}$ for $45 \mathrm{~s}$. After 30 cycles, the DNA products were separated by electrophoresis on $1.5 \%$ agarose gel at $100 \mathrm{~V}$ for $30 \mathrm{~min}$. Finally, gels were stained with $1 \mathrm{mg} / \mathrm{mL}$ EtBr solution and visualized under UV light using CAS-400SM Davinch-Chemiimager ${ }^{\mathrm{TM}}$ (Davinch-K, Geumcheon, Seoul, Korea).

\subsection{Western Blot Analysis}

Protein levels of MMPs were quantified by Western blot assay. Whole proteins from HT1080 cell lines were isolated by RIPA buffer (Sigma Aldrich, St. Louis, MO, USA). Lysed cell lines were loaded onto $12 \%$ sodium dodecyl sulfate-polyacrylamide gel and electrophoresis was conducted at $100 \mathrm{~V}$ for $90 \mathrm{~min}$. Then, separated proteins were transferred onto a nitrocellulose transfer membrane (Whatman ${ }^{\circledR}$, Maidstone, Kent, UK), blocked with $5 \%$ skim milk (BD, Franklin Lakes, NJ, USA) in 1X TBST buffer (LPS solution, Daedeok, Daejeon, Korea), incubated with primary antibodies (MMP-9, MMP-2 and $\beta$-actin) (Cell signaling, Danvers, MA, USA) overnight, and then re-incubated with subsequent secondary antibodies at room temperature for $1 \mathrm{~h}$. Immunoreactive proteins were detected using Western Blotting Detection Reagents kit (GE Healthcare, Chicago, IL, USA) and protein bands 
were observed using a CAS-400SM Davinch-Chemi imager ${ }^{\mathrm{TM}}$ (Davinch-K, Geumcheon, Seoul, Korea).

\subsection{Statistical Analysis}

All numerical values that were presented in the current study were the mean of three independent experiments \pm SD. The statistically significant differences between the different groups were determined by employing one-way analysis of variance (ANOVA) using Statistical Analysis System software v9.1 (SAS Institute, Cary, NC, USA). ANOVA was coupled with Duncan's multiple range test as post hoc analysis. The difference between the different groups was accepted as statistically significant when $p<0.05$.

\section{Conclusions}

In the current study, the MMP inhibitory effects of SAL, NZD and LIG were estimated in PMA-stimulated HT1080 cells. The results of this study showed that these compounds are potentially effective blockers of tumor cell migration and metastasis, by inhibiting MMP-2 and MMP-9 expression and activation through regulation of the MAPK signaling pathway. Therefore, the findings and reports from our two recent studies support the fact that these compounds may be potential candidates for the prevention and treatment of tumor progression [34,35]. In the future, further studies are needed to evaluate the MMP inhibitory effects of various derivatives of secoiridoid glycoside, and to understand their mechanisms of action.

Supplementary Materials: The following supporting information can be downloaded at: https:// www.mdpi.com/article/10.3390/ijms23052660/s1.

Author Contributions: Investigation, writing —original draft preparation, visualization, H.K.; data curation, formal analysis, writing - review and editing, C.-S.K.; funding acquisition, methodology, resources, supervision, Y.S. All authors have read and agreed to the published version of the manuscript.

Funding: This work was financially supported by Basic Science Research Program through the National Research Foundation of Korea (NRF) funded by the Ministry of Science and ICT (No. 2019R1F1A1059325).

Institutional Review Board Statement: Not applicable.

Informed Consent Statement: Not applicable.

Data Availability Statement: The data presented in this study are available on request from the corresponding author.

Conflicts of Interest: The authors declare no conflict of interest.

\section{References}

1. Moss, L.A.S.; Jensen-Taubman, S.; Stetler-Stevenson, W.G. Matrix metalloproteinases: Changing roles in tumor progression and metastasis. Am. J. Pathol. 2012, 181, 1895-1899. [CrossRef] [PubMed]

2. Thomas, N.V.; Kim, S.-K. Metalloproteinase inhibitors: Status and scope from marine organisms. Biochem. Res. Int. 2010, 2010, 845975. [CrossRef] [PubMed]

3. Yoon, A.; Hurta, R.A. Insulin like growth factor-1 selectively regulates the expression of matrix metalloproteinase-2 in malignant H-ras transformed cells. Mol. Cell Biochem. 2001, 223, 1-6. [CrossRef] [PubMed]

4. Verma, R.P.; Hansch, C. Matrix metalloproteinases (MMPs): Chemical-biological functions and (Q)SARs. Bioorganic Med. Chem. Lett. 2007, 15, 2223-2268. [CrossRef] [PubMed]

5. Amar, S.; Fields, G.B. Potential clinical implications of recent matrix metalloproteinase inhibitor design strategies. Expert Rev. Proteomics. 2015, 12, 445-447.

6. Zheng, H.; Takahashi, H.; Murai, Y.; Cui, Z.; Nomoto, K.; Niwa, H.; Tsuneyama, K.; Takano, Y. Expressions of MMP-2, MMP-9 and VEGF are closely linked to growth, invasion, metastasis and angiogenesis of gastric carcinoma. Anticancer Res. 2006, 26, 3579-3583.

7. Daniele, A.; Zito, A.F.; Giannelli, G.; Divella, R.; Asselti, M.; Mazzocca, A.; Paradiso, A.; Quaranta, M. Expression of metalloproteinases MMP-2 and MMP-9 in sentinel lymph node and serum of patients with metastatic and non-metastatic breast cancer. Anticancer Res. 2010, 30, 3521-3527. 
8. Li, H.; Qiu, Z.; Li, F.; Wang, C. The relationship between MMP-2 and MMP-9 expression levels with breast cancer incidence and prognosis. Oncol. Lett. 2017, 14, 5865-5870. [CrossRef] [PubMed]

9. Funasaka, T.; Hu, H.; Higan, V.; Raz, A. Down-regulation of phosphoglucose Isomerase/autocrine motility factor expression sensitizes human fibrosarcoma cells to oxidative stress leading to cellular senescence. J. Biol. Chem. 2007, 282, 36362-36369. [CrossRef]

10. Kim, Y.-S.; Joh, T.H. Matrix metalloproteinases, new insights into the understanding of neurodegenerativedisorders. Biomol. Ther. 2012, 20, 133-143. [CrossRef]

11. Dufour, A.; Overall, C.M. Missing the target: Matrix metalloproteinase antitargets in inflammation and cancer. Trends Pharmacol. Sci. 2013, 34, 233-242. [CrossRef] [PubMed]

12. Vandenbroucke, R.E.; Libert, C. Is there new hope for therapeutic matrix metalloproteinase inhibition? Nat. Rev. Drug Discov. 2014, 13, 904-927. [CrossRef] [PubMed]

13. Wang, L.; Li, X.; Zhang, S.; Lu, W.; Liao, S.; Liu, X.; Shan, L.; Shen, X.; Jiang, H.; Zhang, W.; et al. Natural products as a gold mine for selective matrix metalloproteinases inhibitors. Bioorg Med. Chem. 2012, 20, 4164-4171. [CrossRef]

14. Fields, G.B. The rebirth of matrix metalloproteinase inhibitors: Moving beyond the dogma. Cells 2019, 8, 984. [CrossRef]

15. Kumar, G.B.; Nair, B.G.; Perry, J.J.P.; Martin, D.B.C. Recent insights into natural product inhibitors of matrix metalloproteinases. Med. Chem. Commun. 2019, 10, 2024-2037. [CrossRef] [PubMed]

16. Kim, H.; Kong, C.-S.; Seo, Y. Inhibitory activity of Ligustrum japonicum fructus on MMP-2 and MMP-9. KSBB J. 2017, 32, 328-334. [CrossRef]

17. Kim, H.; Karadeniz, F.; Kong, C.-S.; Seo, Y. Evaluation of MMP inhibitors isolated from Ligustrum japonicum fructus. Molecules 2019, 24, 604. [CrossRef]

18. Kim, S.J.; Kim, K.S.; Hwang, S.J.; Chon, S.U.; Kim, Y.H.; Ahn, J.C.; Hwang, B. Identification of salidroside from Rhodiola sachalinensis A. Bor. and its production through cell suspension culture. Korean J. Medicinal Crop Sci. 2004, 12, $203-208$.

19. Lee, K.J.; Song, N.-Y.; Ma, J.Y. Isolation and bioactivity analysis of salidroside from Acer tegmentosum using on-line screening HPLC-ABTS ${ }^{+}$assay. KSBB 2014, 29, 124-130. [CrossRef]

20. He, Z.D.; Dong, H.; Xu, H.-X.; Ye, W.-C.; Sun, H.-D.; But, P.-P. Secoiridoid constituents from the fruits of Ligustrum lucidum. Phytochemistry 2001, 56, 327-330. [CrossRef]

21. Machida, K.; Kaneko, A.; Hosogai, T.; Kakuda, R.; Yaoita, Y.; Kikuchi, M. Studies on the constituents of Syringa species. X. Five new iridoid glycosides from the leaves of Syringa reticulata (Blume) Hara. Chem. Pharm. Bull. 2002, 50, 493-497. [CrossRef] [PubMed]

22. Lei, Z.; Chen, H.; Zhang, H.; Wang, Y.; Meng, X.; Wang, Z. Evaluation of matrix metalloproteinase inhibition by peptide microarray-based fluorescence assay on polymer brush substrate and in vivo assessment. Appl. Mater. Interfaces 2017, 9, 44241-44250. [CrossRef] [PubMed]

23. Krueger, J.S.; Keshamouni, V.G.; Atanaskova, N.; Reddy, K.B. Temporal and quantitative regulation of mitogen-activated protein kinase (MAPK) modulates cell motility and invasion. Oncogene 2001, 20, 4209-4218. [CrossRef]

24. Vijayababu, M.R.; Arunkumar, A.; Kanagaraj, P.; Venkataraman, P.; Krishnamoorthy, G.; Arunakaran, J. Quercetin downregulates matrix metalloproteinases 2 and 9 proteins expression in prostate cancer cells (PC-3). Mol. Cell Biochem. 2006, 287, 109-116. [CrossRef] [PubMed]

25. Davidson, B.; Givant-Horwitz, V.; Lazarovici, P.; Risberg, B.; Nesland, J.M.; Trope, C.G.; Schaefer, E.; Reich, R. Matrix metalloproteinases (MMP), EMMPRIN (extracellular matrix metalloproteinase inducer) and mitogen-activated protein kinases (MAPK): Co-expression in metastatic serous ovarian carcinoma. Clin. Exp. Metastasis 2003, 20, 621-631. [CrossRef] [PubMed]

26. Reddy, K.B.; Krueger, J.S.; Kondapaka, S.B.; Diglio, C.A. Mitogen-activated protein kinase (MAPK) regulates the expression of progelatinase B (MMP-9) in breast epithelial cells. Int. J. Cancer 1999, 82, 268-273. [CrossRef]

27. Gialeli, C.; Theocharis, A.D.; Karamanos, N.K. Roles of matrix metalloproteinases in cancer progression and their pharmacological targeting. FEBS J. 2011, 278, 16-27. [CrossRef]

28. Bauvois, B. New facets of matrix metalloproteinases MMP-2 and MMP-9 as cell surface transducers: Outside-in signaling and relationship to tumor progression. Biochim. Biophys. Acta 2012, 1825, 29-36. [CrossRef]

29. Kang, H.; Jang, S.-W. Roles of matrix metalloproteinase-9 in cancer metastasis. Biomed. Sci. Lett. 2014, 20, 103-110. [CrossRef]

30. Li, T.; Xu, K.; Liu, Y. Anticancer effect of salidroside reduces viability through autophagy/PI3K/Akt and MMP-9 signaling pathways in human bladder cancer cells. Oncol. Lett. 2018, 16, 3162-3168. [CrossRef]

31. Ren, M.; Xu, W.; Xu, T. Salidroside represses proliferation, migration and invasion of human lung cancer cells through AKT and MEK/ERK signal pathway. Artif. Cells Nanomed. Biotechnol. 2019, 47, 1014-1021. [CrossRef] [PubMed]

32. Sun, C.; Wang, Z.; Zheng, Q.; Zhang, H. Salidroside inhibits migration and invasion of human fibrosarcoma HT1080 cells. Phytomed. 2012, 19, 355-363. [CrossRef] [PubMed]

33. Dinda, B.; Debnath, S.; Banik, R. Naturally occurring iridoids and secoiridoids. An updated review, part 4. Chem. Pharm. Bull. 2011, 59, 803-833. [CrossRef] [PubMed]

34. Sherif, I.O.; Al-Gayyar, M.M.H. Oleuropein potentiates anti-tumor activity of cisplatin against HepG2 through affecting proNGF/NGF balance. Life Sci. 2018, 198, 87-93. [CrossRef] [PubMed]

35. Wongrattanakamon, P.; Nimmanpipug, P.; Sirithunyalug, B.; Chaiyana, W.; Jiranusornkul, S. Molecular modeling of non-covalent binding of Ligustrum lucidum secoiridoid glucosides to AP-1/matrix metalloproteinase pathway components. J. Bioenerg. Biomembr. 2018, 50, 315-327. [CrossRef] [PubMed] 